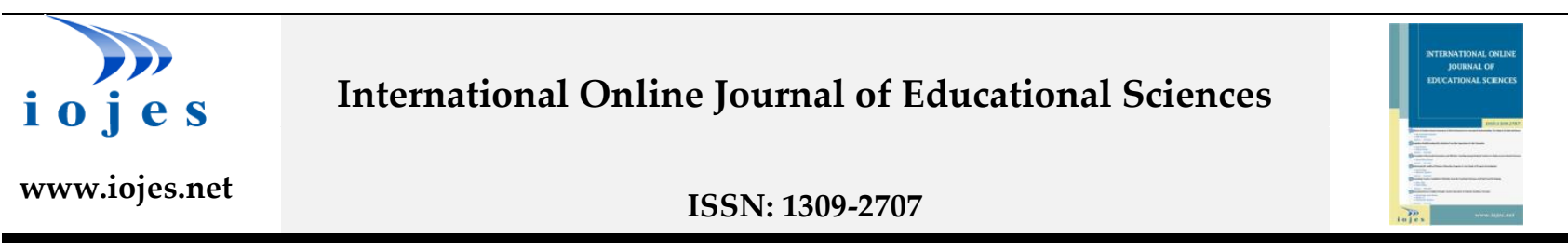

\title{
The Impact of Cooperative Group Work on the Success of the Students in Piano Training
}

\section{Research Article}

\section{Mehmet Kayhan KURTULDU ${ }^{1}$}

${ }^{1}$ Trabzon University, Faculty of Education, Department of Fine Arts Education, Trabzon, Turkey, ORCID: 0000- 0003-0064-9144

To cite this article: Kurtuldu, M. K. (2021). The impact of cooperative group work on the success of the students in piano training, International Online Journal of Educational Sciences, 13(1), 53-64.

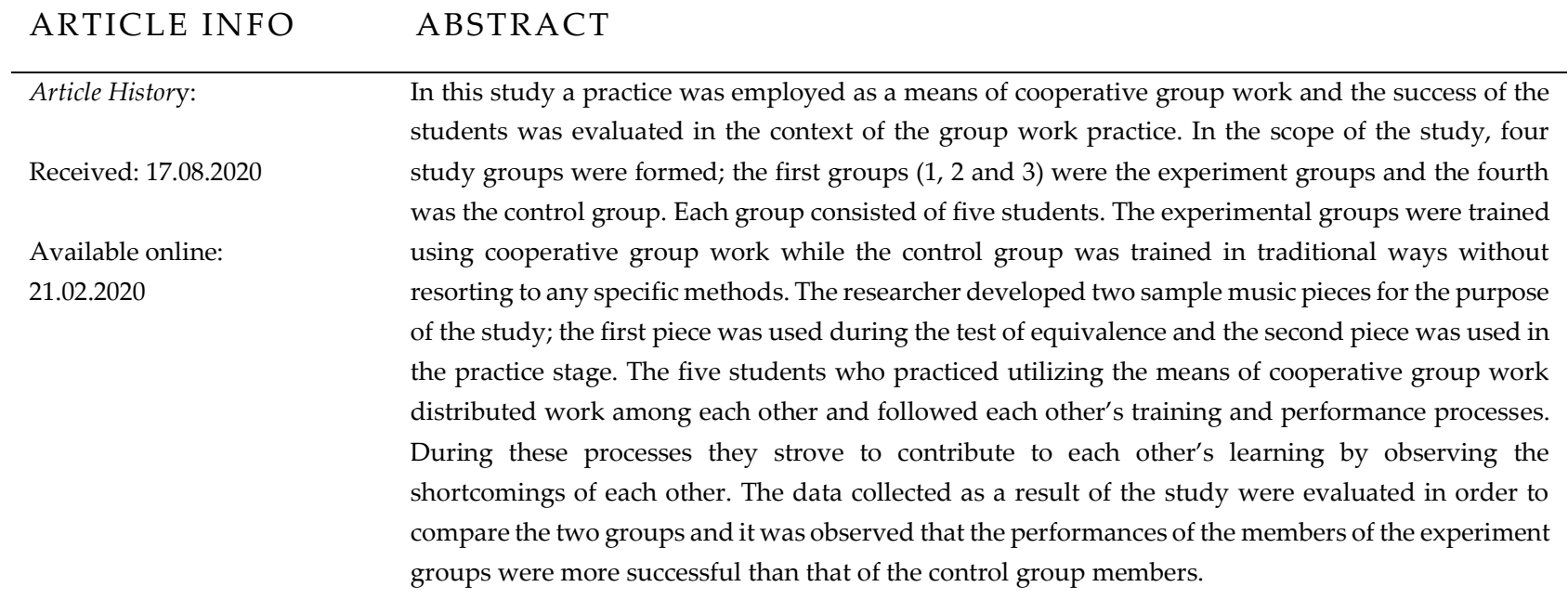

Keywords:

(C) 2021 IOJES. All rights reserved

Piano training, cooperation, group work

\section{Introduction}

Today, a view of education in which students have access, use and provide opportunities to organize the knowledge and which offers situations where they can transform the knowledge into opportunities in accordance with their abilities and potential is generally held. By this view, educators offer various models for effective teaching (Taşdemir, Taşdemir \& Yıldırım, 2009).

Cooperative learning, a topic which has been popularly studied in the recent years, is a method that has positive impacts on cognitive processes like success and memory and in which these impacts are supported by research (Hevedanll, Oral \& Akbayın, 2004). In cooperative learning, it is not a priority for the group

${ }^{1}$ Corresponding author's address: Trabzon Üniversitesi

Telephone: +905326348365

e-mail: kayhankurtuldu@gmail.com

DOI: https://doi.org/10.15345/iojes.2021.01.004 
members to produce pieces by working independently. During the process of learning the important aspect is to work together in interaction with each other (Gök \& Sılay, 2009).

If cooperative learning is simply described, it can be explained as students' learning process in which they work in small groups and help each other learn. (Aç1kgöz, 2004, 172). As according to Artzt and Newman (1990), cooperative learning is an activity in which students work together to solve a problem, accomplish a mission or achieve a common goal as a team (quoted in: Kıncal, Ergül \& Timur, 2007). During the process of cooperative learning, students can structure their own learning in the learning environment. As they discuss with other members of the team, propose solutions and determine the mistakes and then correct them; they develop their high level thinking skills (Ekinci, 2007, 95).

This learning method directs the students to work for their individual best as well as leading them to help each other in a group. By this way, the students acquire constructive approach in their peer relations and gain developed sense of self confidence and success in social relationships (Yllmaz, 2007). The main purpose of constituting cooperative learning groups is to encourage students for acquiring learning responsibilities as a result of increased social interaction (Sharan, Hertz- Lazarowitz \& Ackerman, 1980; Chung-Schickler, 1998; Bilgin \& Karaduman, 2005; Şimşek, Şimşek \& Doymuş, 2006: quoted in Gök, et al. 2009). As Açıkgöz (1992) argued, cooperative learning is a useful and cost-effective method that has positive influences on the affective behaviours and characteristics such as motivation, attitudes, peer relationships, learning environment and self-esteem and on the cognitive learning outcomes such as success, memory, transfer and meta-cognitive processes (quoted in Kincal, Ergül \& Timur, 2007). Cooperative learning activity is seen as an important contribution to the learning process in various fields and many disciplines and studies on the importance of cooperation are on the increase nowadays.

Nowadays it is observed that in the disciplines related to art, cooperative learning actively began to be used. Studies on cooperative learning are observed both in the classroom-level music teaching process and in the instrument training process. Recently, studies on music education such as Kurtuldu (2019), Li (2019), Öztürk and Kalyoncu (2018), Quinn (2016), Compton (2015), Sangiorgio (2015), have also come to the fore.

On this application model which is reinforced with group work especially in music education, Di Natale and Russell (1995), have put forward various opinions. Familiarity between Activities of music groups and cooperative learning applications is one of the subjects that are being ruminated on as a music teaching model. As in cooperative learning, orchestra or similar group work give students the chance to be more responsible and social (Di Natale \& Russell, 1995). Music making requires many qualities that are inherent in cooperative learning: positive interdependence, individual accountability, emphasis on tasks, direct teaching of social skills (as they relate to music making), and frequent teacher observation and intervention (Kassner, 2002). In this context, Cota (2019) also mentions the effects of collaboration in music education such as achieving team commitment, making the right exercises, and mastering great musical works as a result. If musical collaboration is analysed within the framework of its definition and characteristics, musicians will understand how important and complex it is (Cota, 2019).

Many sub techniques of cooperative learning can be adapted to music such as Learning Together, Integration, Student Teams-Success Sections, Team-Game-Tournament, Academic Discrepancy, Group Research, Together We Ask-Together We Learn (Kocabaş \& Uysal, 2006). Group instruction provides students with an understanding of how their problems compare with those of other students and gives them an opportunity to explore alternative solutions suggested by their peers. (Foo, 2005). Besides the views on importance of cooperative learning in music and benefits of group work, various studies have also been made. In the studies explained in the following examples, periodical applications have been made and positive results have been achieved. It is possible to summarize the studies on general music education as follows. 
Kocabaş (1995) have found out that cooperative learning techniques had meaningfully effective in a positive way on Students' attitudes towards music, musical field knowledge, music learning strategies and playing skills. Hwong, et. al. (1993), as a result of music lessons, it was also observed that there was a positive difference in the cooperative learning group in the measurement of pre-test and post-test music attitudes of the candidates. Similarly, a study had been made by Kocabaş and Uysal (2006) about the effect of cooperative learning on the class atmosphere and singing skills. Cornacchio (2008) was observed that cooperative learning is as effective as individual learning in the development of musical skills.

Nacakc1 (2011) had found out that Cooperative learning model is more effective than the standard methods used to acquire musical hearing skills. Sağer et. al. (2015) was aimed to develop polyphonic solfege reading skills through cooperative learning. In a different study, Cangro (2013) had completed cooperative learning practice with a 20 week process. Laurian-Fitzgerald and Mandru (2016), investigated the cooperative learning and improvisation with the fourth grade students. Authors was integrated social studies, arts, literature and maths into a music class during semester and the results showed that every student demonstrated competence in their improvisational skills during the study. In addition to the studies focused on general music education, two different applications for instrument training are summarized as follows. Öztürk and Kalyoncu (2018) recently examined the effect of cooperative learning on anxiety and success in musical hearing lesson. While there was no increase in the success of the musical hearing lesson in the study that lasted for about a semester, there was a decrease in the anxiety about the lesson.

Djordjevic (2007) had made a study on the interaction in the instrumental classroom with 30 high school students; a 6-week collaborative work was conducted during the rehearsals of the end of term concert. Yamamoto (2011) also conducted a musical cooperative performance study and in this study to clarify the difference, the cooperative performance of the drum and the bass was analysed from a rhythmical aspect. At the end of the study results showed that synchronization error between musical rhythms, and fluctuation of musical rhythm became smaller in cooperated performance. The situation of cooperative practices in some academic studies within the scope of piano education has been tried to be summarized as follows.

Güven and Çevik (2011) have prepared a sample lesson plan to use during the process of piano education in their study. In a study based on piano learning with small groups, Daniel (2003) has been informed from the students that studying with group is educatory. Deniz (2015), on the other hand, had conducted a cooperative study with three students on six hands piano. As a result of the study, a successful performance, good motivation and social skills among the group were some important gains. Besides these, Meulink (2011), in his study on cooperative learning in group piano teaching, had done group learning activities and achieved positive results. In a cooperative practice done by Fischer (2006), university students had been aimed to work cooperatively in group piano lessons. In a study named as Profiles in successful group piano for children: a collective case study of children's group-piano lessons Pike (2013) aimed to explore the best practices in beginning group-piano instruction. Observations, interviews and questionnaires showed that Students displayed the ability to analyse new music, persist in learning it and make music with peers. Recently, $\mathrm{Li}$ (2019) examined the effect of cooperative learning on the development of harmony skills in piano education. As a result of the experimental study, the piano performances of the participants increased towards the post-test.

In view of the above opinions, definitions and thoughts; in this study, it has been examined whether a piano study process based on cooperative learning has an effect on the success of the students. We come across with cooperative studies either in the method of teaching with group or helping each other. These views also helped to address the different aspects of cooperation and to try and transform it into academic work. And in this study, it was aimed to organize the extra-curricular work process which takes an important place in the piano education process and to obtain benefit from this collaborative arrangement. 
Today, practices focused on group piano training are carried out in piano training processes. In these applications, the interaction between different piano works and individuals who study piano in the same classroom environment is examined. In these environments, the teacher is also responsible for lecturing and following more than one person. The practice conducted in this study, unlike group piano training, involves students working on the same piece by helping each other and interacting in a collaborative way. In group piano education, students observe each other. In this application, students help each other. Therefore, the study includes collaborative practices such as cooperating, monitoring and evaluating each other in piano education. When examined in general, we come across studies focused on group piano education in the literature. From this point of view, this study of students who improve each other's performance through a collaborative study gains importance in terms of the literature.

\section{Method}

In the study, an experimental method was preferred, cooperative group work was planned and applied comparatively. Cooperative learning theory was not applied to the piano teaching process the same way in the study. A cooperative group study (a group work based on cooperative view and working together) was planned utilizing working with group and intergroup interaction/evaluation steps of the collaborative learning theory.

\section{Study Group}

The study group consisted of 20 students from the students of the Music Teaching Program at Fatih Faculty of Education in Karadeniz Technical University. 20 students were divided into four sample groups; the first three groups (five students per group) in constituted the experiment group whereas the rest made up the control group. The sample groups were selected randomly among the $4^{\text {rh }}$ year (senior) students of the Program in the Spring Semester of the 2018-2019 Academic Year. Students are in the age range of 21 and 25. In the music teacher program, the piano lesson is carried out until the senior level. For this reason, the students have been selected from the senior classes as they might be more conscious and mature to fulfil the monitoring task in the cooperative task. Before the study group was identified, the achievement of the piano lessons of the senior students was examined and a list of at least intermediate level (the most basic course passing grade CC success grade) and the above ones has been prepared. 20 people have been selected randomly from the list regardless of the notes. For this study three experimental groups and a control group was consisted. These three experimental groups were formed to examine the group work effect more effectively. It was observed that effect of the group work and student success level will be repetitive or not in each groups. However control group data was used only comparing measurements, so forming only one control group has mentioned as adequate.

\section{Data Collection (Application of the Method)}

The applications used in the study included the equivalence test and the experimental test that were applied on the experiment and control groups. Two different musical pieces was written by the researcher because of other piano literature pieces can be known (listened or played by the students) before. The group members practiced the first piece individually for 30 minutes, and at the end of the practice the performances of the students were recorded with a video camera and evaluated. This first stage was designed as the "equivalence test". In this test no specific methods were used and each student practiced the piece under same conditions (time, piece, environment, etc.). After the test of equivalence, the groups were split from each other to practice separately. First, the second sample piece was practiced with the control group without using any specific methods as they did in the equivalence test. At this second stage, the practice period and the practice plans of both groups were kept equal except when the experiment groups practiced the piece using cooperative work. 
In the experimental application, first the control group was asked to practice the second musical piece for 30 minutes individually after receiving it in order to get familiar with the piece. At the end of 30 minutes practice the students performed under the supervision of the teacher and the note sheets were collected from each student to be returned them the following day for re-application. The first day's practice was named as the pre-application and then the study passed into the main application stage that would be repeated for the next two days. The next day the students were called again and this time they were asked to practice the same for an hour. After the practice their performances were observed by the teacher. After the performances, the note sheets were collected again and the students were called back for a second day for the same application. In the second day of the main application period the students again practiced for an hour and their performances were followed by the teacher. After a 30 minutes break the students gave their final performances that were recorded with video camera and the study with the control group ended. During the study with the control group each student practiced independently. To allow the students practice alone, each student in the control group were called in different times.

Following the completion of the control group section of the study, experiment group section of the study was started. As in the previous section with the control group, the experiment groups were first asked to practice individually for thirty minutes. In the first individual practice session, each student received the sample piece at the same time but they were placed in different rooms for practice. Except this first individual practice application that was intended to allow the students get familiar with the sample musical piece, all the other practices and performance hearings were made together in cooperation and under the supervision of the teacher. The different approach applied to the experiment groups than the control group is that the studies after the first half hour of preliminary study were carried out in a cooperative manner. The work plan continued with one hour sessions of practice and performance in the following two days. At the end of each day the note sheets were collected back from the students and on the second day of the main application the student performances were recorded with a video camera after a break of 30 minutes. The study ended with the completion of recording.

Except the stages of getting familiar with the musical piece and video recording of the final performances for evaluation, each student assessed each other's practice and performance processes during the cooperative learning practice. The students were directed to divide work between each other in the experiment groups. Each student monitored the other members of the group both in practice and performance sections and the students criticized and assessed each other. During the implementation of the study when a student practiced the others listened to him/her and based on the division of work they watched their peers' performances. In the division of responsibilities, one of the four students who were assigned to watch followed wrong notes played, the others were responsible for following the synchronization of the left and right hands, playing technique and the nuance terms, respectively. During the one-hour practice sessions and the following performance stages the students cooperatively watched each other and they tried to correct each other's mistakes by providing assessments.

Each student who practiced on the piano assumed the monitoring role of the peers following his/her turn. By this way, each student practiced for one hour under the others' surveillance and evaluation and the observation continued during the performing sessions under the supervision of the teacher. The students who monitored each other and practiced in cooperation worked with the awareness of their mistakes and the necessary corrections thanks to the comments and critiques coming from their peers. The students in the experiment groups shared with each other the shortcomings that they identified after each monitoring on the performed work. In other words, students criticized each other's performances. The cooperative application for the experimental group was repeated for the students in all other experimental groups. 


\section{Data Collection Tool}

By means of observation after the applications, the piano exam evaluation scale developed by Kurtuldu (2010) was implemented in calculating the success scores of the students needed for the test. The scale that is used is a measure that evaluates any piano pieces in student level. The scale includes basic evaluation steps such as playing correct notes, correct rhythm patterns, two-hand synchronization, tempo continuity, nuances and technical skills. The scoring key contains 6 evaluation steps as above. Assessment levels have score distribution in the form of playing correct notes (20 points), correct rhythm patterns (15 points), two-hand synchronization (10 points), tempo continuity (20 points), nuances (15 points) and technical skills (20 points). . The scoring key was measured by Kurtuldu (2010) with the correlation between individuals who made the assessment. In these measurements, 5 piano educators made evaluations and the correlation between them was found to be over +700 and +800 points, positive and high.

Table 1. Work Plan Schedule

\begin{tabular}{|c|c|c|c|c|c|c|}
\hline Groups & 1. session & Performing & 2. session & Performing & 3. session & Performing \\
\hline $\begin{array}{l}\text { Experiment } \\
\text { Groups }\end{array}$ & $\begin{array}{l}\text { Free Practice } \\
\text { (1/2 hour) }\end{array}$ & $\begin{array}{c}\text { Performing under } \\
\text { teacher } \\
\text { supervision } \\
\text { (cooperative) }\end{array}$ & $\begin{array}{c}\text { Working together } \\
\text { (cooperative/1 } \\
\text { hour) }\end{array}$ & $\begin{array}{c}\text { Performing under } \\
\text { teacher } \\
\text { supervision } \\
\text { (cooperative) }\end{array}$ & $\begin{array}{c}\text { Working together } \\
\text { (cooperative/1 } \\
\text { hour) }\end{array}$ & $\begin{array}{c}\text { Final } \\
\text { individual } \\
\text { performance }\end{array}$ \\
\hline $\begin{array}{l}\text { Control } \\
\text { Group }\end{array}$ & $\begin{array}{l}\text { Free Practice } \\
\text { ( } 1 / 2 \text { hour) }\end{array}$ & $\begin{array}{c}\text { Performing under } \\
\text { teacher } \\
\text { supervision }\end{array}$ & $\begin{array}{c}\text { Free Practice (1 } \\
\text { hour) }\end{array}$ & $\begin{array}{l}\text { Performing under } \\
\text { teacher } \\
\text { supervision }\end{array}$ & $\begin{array}{c}\text { Free Practice (1 } \\
\text { hour) }\end{array}$ & $\begin{array}{c}\text { Final } \\
\text { individual } \\
\text { performance }\end{array}$ \\
\hline
\end{tabular}

\section{Data Analysis}

The use of non-parametric comparison tests in the analysis of data collected from a study group of 20 people was deemed appropriate. Since the total number of the study group was small (less than 30 people), normality assumption was not tried and non-parametric tests were applied. Ravid (1994) suggested that there may be deviations from normality if the sample is smaller than 30 people for various measurements (quoted in Büyüköztürk, et al. 2017). Similarly, Can (2017, p.82) pointed to the figure of 30 as the lower limit and claimed that the probability of normal distribution is weak in the groups below this number.

After the implementation of the application the scores of the students obtained from the equivalence test and the experimental test processes were statistically tested. In the statistical measurements the equivalence test scores of the all 20 students who constituted the experiment and control groups were compared using the Kruskal Wallis $\mathrm{H}$ test. In order to compare the cooperative application scores derived after the equivalence test and for the analysis of the experimental application $\mathrm{H}$ test was preferred as a means of calculation. The significance level was taken as $p<.05$ in the tests administered.

The Kruskal Wallis $\mathrm{H}$ test is a non-parametric test that is independent of each other and compares the measurements of more than two groups for a dependent variable and whether there is a significant difference between them. In this test, median (median) scores are taken into account instead of average scores compared to other parametric tests (Ural, K1lı̧, 2018, p. 257).

\section{Findings}

In this section, the scores of the $U$ test that was implemented on the data derived from the experiment and control groups were classified in a table with the scores of the pre-test and the end-test and the average scores of each group were also presented in order to see the improvement levels. 
Table 2. Success Scores of the Groups

\begin{tabular}{cccccccccccc}
\hline $\begin{array}{c}\text { Experiment } \\
\text { Group1 }\end{array}$ & $\begin{array}{c}\text { Pre- } \\
\text { test }\end{array}$ & $\begin{array}{c}\text { End- Experiment } \\
\text { test }\end{array}$ & $\begin{array}{c}\text { Pre- } \\
\text { Group2 }\end{array}$ & $\begin{array}{c}\text { End- Experiment Pre- } \\
\text { test }\end{array}$ & $\begin{array}{c}\text { End- } \\
\text { test }\end{array}$ & $\begin{array}{c}\text { Control } \\
\text { Group3 }\end{array}$ & $\begin{array}{c}\text { Pre- } \\
\text { test }\end{array}$ & $\begin{array}{c}\text { End- } \\
\text { test }\end{array}$ & Group & test & test \\
\hline 1 & 75 & 92 & 1 & 71 & 90 & 1 & 78 & 92 & 1 & 72 & 80 \\
\hline 2 & 75 & 90 & 2 & 75 & 90 & 2 & 80 & 95 & 2 & 75 & 80 \\
\hline 3 & 70 & 90 & 3 & 75 & 95 & 3 & 75 & 90 & 3 & 78 & 78 \\
\hline 4 & 70 & 95 & 4 & 65 & 93 & 4 & 70 & 89 & 4 & 80 & 80 \\
\hline 5 & 68 & 92 & 5 & 70 & 90 & 5 & 80 & 97 & 5 & 72 & 78 \\
\hline
\end{tabular}

When Table 2 is analysed, it is observed that the groups had closer scores in the pre-test and both increased scores in the end-test. As expected, the students of each groups increased their scores after practicing the musical piece but the real substantial increase was observed in the scores of the experiment groups based on the application of this study.

Table 3. H Test Scores on the Pre-test Scores

\begin{tabular}{cccccc}
\hline Groups & $\mathbf{n}$ & Mean Rank SD & $\mathbf{d f}$ & $\boldsymbol{X}^{2}$ & $\mathbf{p}$ \\
\hline Experiment 1 & 5 & 8,40 \\
Experiment 2 & 5 & 8,60 \\
\hline Experiment 3 & 5 & 11,50 \\
\hline Control & 5 & 13,90 & & & \\
\hline
\end{tabular}

According to the $\mathrm{H}$ test results shown on Table 3, no significant difference was observed in pre-test results based on $\mathrm{p}<.05$ level $\left[X^{2}=2,69, \mathrm{p}<, 05\right]$. When the mean rank values are examined, it is seen that the average values of the groups are close to each other. This situation indicates that there is an equivalent performance situation between the experimental groups and the control group in the pre-test application.

Table 4. H Test Scores on the End-test Scores

\begin{tabular}{ccccccc}
\hline Groups & $\mathbf{n}$ & Mean Rank & SD & df & $X^{2}$ & p \\
\hline Experiment 1 & 5 & 13,00 & & & & \\
\cline { 1 - 3 } Experiment 2 & 5 & 12,50 & & & \\
\cline { 1 - 3 } Experiment 3 & 5 & 13,50 & 3 & 11,19 &, 011 \\
\hline Control & 5 & 3,00 & & & \\
\hline
\end{tabular}

When Table 4 is examined, it is understood that there is a significant difference between the groups according to the $\mathrm{p}<, 05$ level. The tendency for the significant difference based on the mean rank values is in the direction of the experimental groups. The rank values of the experimental groups are quite close to each other, but better than the control group. The fact that the experimental group students' scores are close can be interpreted as the same success was similarly repeated in all experimental groups.

\section{Conclusion}

The data obtained from the application of the study and the results derived from the analysis of the data demonstrated that the experiment groups achieved more improvement and success than the control group. Based on the findings of the study, it can be argued that working cooperatively in piano training by using this method can positively affect the success of the students. The students who work in cooperation put more successful performances than those students who practiced freely in traditional ways. During the process it was observed that the members of the experiment groups enjoyed their practice and they utilized the motivation that the cooperative group work gave them in positive direction. These students had the opportunity to spot the potential mistakes beforehand and practice accordingly. Therefore, it is possible to 
place cooperative group work among those different methods effective in increasing the success of the students.

When this study is compared with some other studies within the scope of piano education, it is possible to come across different or similar aspects. Cota (2019) followed an experimental method in his study, focused on the development of different mechanical skills with people playing duo on the piano, and observed that interpersonal communication increased. While the study is similar to this study in terms of the experimental method, unlike our study, a success has been achieved in general terms in the performance of the piece. In the study conducted by Li (2019), an experimental method was used, large group work was conducted with college students, focusing on the ability to play harmony on the piano, and attitudes towards playing harmony increased. The situation, which is similar in terms of the use of experimental methods, is different in that our article focuses on the development of performance skills on the piano. Meulink (2011) also conducted a collaborative study with the group in the piano education class and focused on longer-term skill developments such as sight-reading, accompaniment, improvisation, and harmonization. In our article, instead of group piano training, collaborative cooperation between small groups is included, and generally, the focus is on playing piano skills. Deniz (2015), on the other hand, worked on playing skills and motivation in playing sixhand piano pieces. A study with a single group is different from the experimental and control group measurement in our article. On the other hand, Deniz (2015) also focused on motivation in her study.

Sağer et al. (2015) emphasized the importance of the concepts of friendship and teamwork in their studies on cooperative learning. Likewise, Yeşilyurt (2009) emphasizes that this method helps students to get to know each other better. It also emphasizes the development of friendship, friendship and empathy feelings of cooperative learning. Vilda et al. (2019) emphasized teamwork skill, good friendship and social communication for this method, while also referring to the development of students' learning together and their own learning skills. On the other hand, Kurtuldu (2019) attributes the collaborative method to its prominence, the fact that it includes group work, it is about friendship and it includes enjoyable activities. Macit and Aslaner (2019) stated that interaction, as well as teamwork and friendship, are among the factors that bring success in cooperative learning. Baştürk and Bektaş (2019) similarly emphasized the importance of this interaction and stated that the quality of the learning environment is related to the level of this interaction.

Şimşek et al. (2006) mentions that cooperative learning has many benefits such as problem solving, developing skills, taking responsibility, using effective learning strategies, providing personal and interpersonal responsibility, self-esteem, helping each other and motivation. Bayrakçeken et al. (2015) also cites the benefits of cooperative learning such as improving thinking skills, increasing abilities, increasing communication skills, increasing knowledge, improving communication and empathy skills, increasing willingness to work together, motivation and self-esteem. Senemoğlu (2005) also referred to similar benefits (self-esteem, motivation, friendship, etc.), as well as benefits such as active participation in learning, attention and maintenance of motivation, higher-order thinking skills, commitment and belonging.

Success increases when the above-mentioned benefits of cooperative learning are reflected in the learning environment. In this study, it is possible to list issues such as friendship, teamwork, and interaction among the reasons for the success achieved in the experimental groups. All these issues in the abovementioned studies can be listed among the main basis and reasons for the success achieved in this study. The students felt connected to each other in their study, enjoyed their work, and were more motivated to the subject and the piano instrument. The perceptions and analysis skills of the students, whose self-confidence increased, about the work they were working on also came to the fore. Both the benefits of cooperative learning and the issues mentioned above within the scope of the factors that emphasize cooperative learning are the characteristics that have contributed to the success of the students in this study. The aforementioned feeling of pleasure and friendship in working together (Bayrakçeken et al.2015; Sağer, et.al.2015; Vilda et al. 2019; 
Kurtulmuş, 2019; Macit and Aslaner, 2019), empathy and social communication (Vilda et al. Benefits such as 2019; Yeşilyurt, 2009), interactive learning environment (Baştürk and Bektaş, 2019), skill development, attention development, using learning strategies, increased motivation (Şimşek et al.2006; Bayrakçeken et al. 2015; Senemoğlu, 2005), there may be key concepts in students' success.

In conclusion, studying the exams or musical pieces by utilizing cooperative group work in piano training is important from the aspects of developing group work skills and creating more effective impacts on learning. The students can increase their success by using the cooperative method like other supplementary methods that can be effective in the piano training process. On the other hand, applications based on observation and cooperation can not only develop the learning skills of the students but also their teaching skills. The students that observe and evaluate each other in cooperative framework will be assured to see the fruits of their education and especially their knowledge on the learning methods leading to more improvement. Based on the findings of this study, it can be recommended that the students can be assigned in sample work groups that are formed with the intention of increasing success with cooperative piano training. It can also be advised that similar studies can be conducted with different experiment and control groups in different time frames. 


\section{REFERENCES}

Açıkgöz, K. Ü. (2004). Active learning. (6 $6^{\text {th }}$ Edition), İzmir; Eğitim Dünyası Publications.

Baştürk, G. \& Bektaş, M. (2019). Examination of metaphorical perceptions of 4th grade students on the concept of collaboration. International Journal of Field Education, 5(1), 71-87.

Bayrakçeken, S., Doymuş, K. \& Doğan, A. (2015). Cooperative learning model and its application. Ankara: PegemA Publications.

Bozdoğan, A. E., Taşdemir, A \& Demirbaş, M. (2006). Impact of cooperative learning method on development of scientific process skills of students in teaching of science. İönü University, Journal of Faculty of Education, 7(11), 23 - 36 .

Büyüköztürk, Ş. (2004). Data analysis manual in social sciences. Ankara; PegemA Publications.

Büyüköztürk, Ş., Çokluk, Ö. \& Köklü, N. (2017). Statistic for social science. Ankara PegemA Publications.

Can, A. (2017). Data analysis in scientific research process with SPSS. Ankara: PegemA Publications.

Cangro, R. M. (2013). Effects of cooperative learning strategies on the music achievement of beginning instrumentalists. International Journal of Arts and Commerce, 2(79), 133 - 141.

Cornacchio, R. A. (2008). Effect of cooperative learning on music composition, interactions and acceptance in elementary school music classrooms. Unpublished Doctoral Dissertation, School of Music and Dance and the Graduate School of the University of Oregon.

Compton, K. R. (2015). An investigation of the effectiveness of cooperative learning as a rehearsal technique for improving high school band performance. Unpublished Doctoral Dissertation, College of Fine Arts at the University of Kentucky.

Cota, M. (2019). Interpersonal aspects of musical collaboration for collaborative pianists. Unpublished Doctoral Dissertation, Arizona State University.

Daniel, R. J. (2003). Advanced student small group piano teaching: an investigation of extant models in practice and reflection on these models. 6th Australasian Piano Pedagogy Conference, 1 - 5 July, Victorian College of the Arts, Melbourne, Australia.

Deniz, J. (2015). The effectiveness of cooperative learning method on teaching six hands piano piece: an action research. The Journal of Academic Social Science, 3(15), 89 - 117.

Di natale, J. J. \& Russell, G. S. (1995). Cooperative learning for better performance. Music Educators Journal, $82(2), 26-28$.

Djordjevic, S. A. (2007). Student perceptions of cooperative learning in instrumental music. Unpublished Master Dissertation, USA: University of Michigan.

Ekinci, N. (2007). New trends in education. Ö. Demirel (Ed.), Cooperative Learning (pp. 93-109), Ankara: PegemA Publishing.

Fisher, C. C. (2006). Applications of selected cooperative learning techniques to group piano instruction. Unpublished Doctoral Dissertation, University of Oklahoma Graduate College.

Foo, C. O. (2005). Group piano teaching: an interactive and experiential approach. 7th Australasian Piano Pedagogy Conference, 12 - 16 July, University of Adelaide.

Gök, T. \& S1lay, İ. (2009). Impact of teaching problem solving strategies on success motivation of students in cooperative learning groups. Kastamonu Education Journal, 17(3), 821 - 834. 
Güven, E. \& Çevik, D. B. (2011). A lesson plan proposal for cooperative learning in piano education. International Education Technology Conference, 25 - 27 May, Istanbul, Turkey.

Hevedanl, M., Oral, O. \& Akbayın, H. (2004). Effects of cooperative learning and traditional teaching methods on students' achievement and retention in teaching biology. XIII. National Education Sciences Congress, 6 - 9 July, Malatya, Turkey.

Hevedanlı, M. \& Akbayın, H. (2006). Impact of cooperative learning method on success, bearing in mind and attitudes towards the subject in teaching biology. Dicle University Journal of Ziya Gökalp Education Faculty, $6,21-31$.

Hwong, N. C., Caswell, A., Johnson, D. W. \& Johnson, R. T. (1993). Effects of cooperative and individualistic learning on prospective elementary teachers' music achievement and attitudes. The Journal of Social Psychology, 133(1), $53-64$.

Kıncal, R. Y., Ergül, Y. \& Timur, S. (2007). Impact of cooperative learning on student success in teaching sciences. Hacettepe University Journal of Education, 32, 156 - 163.

Kocabaş, A. \& Uysal, G. (2006). Effect of cooperative learning over the classroom atmosphere and singing ability in elementary music teaching. National Music Education Symposium, 26 - 28 April, Pamukkale University, Denizli/Turkey.

Kocabaş, A. (1995). The effects of cooperative learning on soprano recorder teaching and learning strategies. Unpublished Doctoral Dissertation, Dokuz Eylül University Social Science Institute.

Kumaş, A. \& Saka, A. Z. (2009). A problem-based learning practice in cooperative learning groups: projectile motion practice case, $1^{\text {st }}$ International Educational Researches Congress, May 1 - 3, Onsekiz Mart University, Çanakkale.

Kurtuldu, M. K. (2010). Validity and reliability of piano examination evaluation scale for evaluators. Electronic Social Sciences Journal (Esosder), http://www.e-sosder.com/ (ISSN: 1304 -0278), 9(31), 224 - 232.

Kurtuldu, G. (2019). A Study about teaching a gain named as "Distinguish Primary Music Kinds in Our Country" stated in secondary school curriculum by using cooperative learning. Unpublished Master Thesis. Trabzon University, Graduate Education Institute.

Kurtuluş, Y. (2001). Cooperative learning in art education. Hacettepe University Journal of Education, 20, 201 205.

Laurian-Fitzgerald, S. \& Mandru C. (2016). Cooperative learning and improvisation: engaging fourth grade students in music. Olah, Ş et. al. (Ed.), Current Challenges in Social Sciences, Cluj-Napoca; Cluj University Publications.

Li, Y. (2019). The effects of collaboration on harmonization in college group piano. Unpublished Doctoral Dissertation, Graduate Faculty of the Louisiana State University

Macit, E. \& Aslaner, . (2019). Views of teacher on using cooperative learning in math lessons at primary school. Journal of Science, Mathematics, Entrepreneurship and Technology Education, 2(2), 134 - 157.

Meulink, J. N. (2011). Cooperative learning methods for group piano: The development of a teaching guide. Unpublished Doctoral Dissertation, Ball State University Muncie, Indiana, USA.

Nacakc1, Z. (2011). Effect of cooperative learning to student success in "musical hearing reading and writing" lesson. E-Journal of New World Science Academy, 6(2), 180 - 186. 
Öztürk, G. \& Kalyoncu, N. (2018). The effect of cooperative learning on students' anxiety and achievement in musical ear training lessons. Journal of Measurement and Evaluation in Education and Psychology, 9(4), 365375.

Pike, P. D. (2013). Profiles in successful group piano for children: a collective case study of children's grouppiano lessons, Music Education Research, 15(1), 92 - 106.

Quinn, S. (2016). Exploring the meaning of cooperative learning in four Grade 3 music classrooms. Unpublished Master Thesis, North-West University.

Sağer, T. Gürpınar, E. \& Zahal, O. (2015). The effect of applications to polyphonic solfeggio terms based on cooperative learning method. Hacettepe University Journal of Education, 30(1), 195 - 212.

Sangorio, A. (2015). Collaborative creativity in music education: Children's interactions in group creative music making. Unpublished Doctoral Dissertation, University of Exeter.

Senemoğlu, N. (2005). Development learning and teaching from theory to application. Ankara: Gazi Bookstore.

Şimşek, U., Şimşek, Ü. \& Doymuş, K. (2006). A review on cooperative learning method III: The useful in education environment of cooperative learning method. Atatürk University Kazım Karabekir Faculty of Education Journal, 13, $414-430$.

Taşdemir, M., Taşdemir, A. \& Yıldırım, K. (2009). Influence of portfolio evaluation in cooperative learning on student success. Journal of Theory and Practice in Education, 5(1), 53 - 66.

Ural, A. \& Kılıç, İ. (2018). Scientific research process and data analysis with SPSS. Ankara: Detay Publishing.

Vilda, V., İrdem, K., Ustam, F. Çamlıca, A., Devecioğlu-Gözügüzel, Ö., Bayraktar-Cellatoğlu, B., Denizli, Ö. \& Dervişoğulları, K. (2019). Determination of primary school teachers' views on cooperative learning. International Journal of New Trends in Arts, Sports \&Science Education, 8(4), $113-12$.

Yamamoto, T. (2011). Synchronization and fluctuation of rhythm in musical cooperative performance. 14th International Conference, Human Computer Interaction, 9 - 14 July, Orlando, USA.

Yeşilyurt. E. (2009). The views of students on the effect of cooperative learning on student behaviours. Firat University Journal of Social Science, 19(2), 161-178.

Yllmaz, M. (2007). Cooperative learning in visual arts education, Kastamonu Education Journal, 15(2), 747 - 756. 